\title{
Bacterial Leakage in Root Canals Filled with Calcium Hydroxide Paste Associated with Different Vehicles
}

\author{
Cristiana MURAD ${ }^{1}$ \\ Luiz Fernando FARINIUK ${ }^{2}$ \\ Sandra FIDEL ${ }^{1}$ \\ Rivail Antonio Sergio FIDEL ${ }^{1}$ \\ Luciana Moura SASSONE ${ }^{1}$
}

\author{
${ }^{1}$ ProClin Department, State University of Rio de Janeiro, Rio de Janeiro RJ, Brazil \\ ${ }^{2}$ Department of Endodontics, Pontifical Catholic University of Paraná, Curitiba, PR, Brazil
}

\begin{abstract}
This in vitro study evaluated, using a bacterial leakage model, whether intracanal medication with calcium hydroxide $\left[\mathrm{Ca}(\mathrm{OH})_{2}\right]-$ based pastes prepared with different vehicles, has inhibitory effect on corono-apical leakage of bacteria. Forty instrumented human canines were dressed with $\mathrm{Ca}(\mathrm{OH})_{2}$ p.a. associated with: $\mathrm{G} 1=$ distilled water; $\mathrm{G} 2=$ polyethylene glycol $(\mathrm{PG}) ; \mathrm{G} 3=\mathrm{PG}+\mathrm{CMCP}$; and $\mathrm{G} 4=$ glycerin. Five teeth with intact crowns served as negative controls and 5 instrumented teeth without temporary dressing served as positive controls. All teeth were mounted in a 2-chamber apparatus and then exposed to human saliva for 63 days. Leakage was recorded when turbidity was observed in the lower chamber. Fifty percent of the samples of G1 and G2, 10\% of G3 and $80 \%$ of G4 were fully contaminated after 9 weeks. Statistically significant differences were observed with paired comparisons G3 and G4 ( $\mathrm{p}=0.0069$ ), with $\mathrm{G} 3$ achieving better seal against bacterial leakage than $\mathrm{G} 4$.
\end{abstract}

Key Words: bacterial leakage, calcium hydroxide, vehicles.

\section{INTRODUCTION}

Apical periodontitis is caused by intracanal bacteria and their byproducts in the root canal system. Although chemomechanical preparation of infected root canals has been shown to be effective in reducing the root canal microbiota, viable microorganisms can be often isolated in the posttreatment period (1). Such residual microorganisms and their byproducts remaining in the apical portion of the root canal or in the dentinal tubules may be a cause of endodontic failure (2). Another important reason for the clinical failure of endodontic therapy is coronal leakage (3). Inadequate coronal fill or microleakage around temporary filling may result in root canal contamination. In some cases, the placement of intracanal dressings is necessary to enhance the bactericidal effect and also to create a physical barrier that may both prevent canal reinfection and marginal leakage, and interrupt the nutrient supply to the remaining bacteria (4). However, whether interappointment temporary filling materials provide an adequate seal of the root canal system from contamination between sessions may still be questionable (3).

Calcium hydroxide $\left[\mathrm{Ca}(\mathrm{OH})_{2}\right]$ has been largely used as an intracanal dressing, mostly due to its antimicrobial activity against most endodontic pathogens (5). The antimicrobial effects of calcium hydroxide relate directly to its high $\mathrm{pH}$ (12.5), it has a destructive effect on cell membranes and protein structures. The action of calcium hydroxide is dependent on its dissociation and the release of hydroxyl ions $\left(\mathrm{OH}^{-}\right)$, which will diffuse into surrounding tissues (6).

Different vehicles have been added to $\mathrm{Ca}(\mathrm{OH})_{2}$ in an attempt to improve its antimicrobial activity, biocompatibility, speed of ionic dissociation and diffusion. There are a variety of vehicles, which can be 
aqueous, viscous or oily, that may be used to make calcium hydroxide pastes (5).

The purpose of this study was to evaluate the ability of intracanal dressings in preventing interappointment coronal leakage of canals medicated with $\mathrm{Ca}(\mathrm{OH})_{2}$-based pastes associated with different vehicles, using a polymicrobial leakage model for leakage assessment.

\section{MATERIAL AND METHODS}

\section{Sample Selection and Preparation}

This study was reviewed and approved by the Research Ethics Committee of the Nucleus of Collective Health Studies, State University of Rio de Janeiro, Brazil.

Fifty human maxillary canines were selected from the tooth bank of the State University of Rio de Janeiro and autoclaved. Forty-five teeth were prepared as follows. Standardized clinical coronal accesses were made and all root canal orifices were located. The patency of each canal was confirmed by inserting a size 10-K file (Dentsply/Maillefer Instruments SA, Ballaigues, Switzerland) through the apical foramen (AF) and the working length was established by deducting $1 \mathrm{~mm}$ from the root canal length. Root canals were rinsed with freshly prepared $5.25 \%$ sodium hypochlorite $(\mathrm{NaOCl})$. All teeth were instrumented using GT rotary files (Dentsply/Maillefer Instruments SA) using crown-down technique beginning with flaring files $70.12,50.12,35$ .12 followed by size 20 files, taper $.12, .10, .08$ and .06 for cervical and middle third preparation. The apical portion of the root canal was instrumented with sizes 20 and 25 files, taper .04. The GT rotary instruments were used with a torque-controlled motor, TC Motor 3000 (Nouvag, Goldach, Switzerland) at a rotational speed of $300 \mathrm{rpm}$ and the torque setting at $1.2 \mathrm{Ncm}$.

The root canals were irrigated between each file with $2 \mathrm{~mL}$ of freshly prepared $5.25 \% \mathrm{NaOCl}$. After preparation, the root canal was irrigated with $17 \%$ EDTA (Odacham; Herpo Produtos Dentários LTDA, Rio de Janeiro, RJ, Brazil) for $5 \mathrm{~min}$ and $5.25 \% \mathrm{NaOCl}$ to remove the smear layer, followed by a final flush of distilled water. All teeth were washed in running water during $24 \mathrm{~h}$, for total removal of $\mathrm{NaOCl}$. The canals were dried with paper points (Dentsply/Maillefer) before application of intracanal dressings.

Thereafter, 40 of the 45 instrumented teeth were randomly assigned to 4 groups of 10 teeth each. Temporary dressings with $\mathrm{Ca}(\mathrm{OH})_{2}$ p.a. mixed with 4 different vehicles were used, as follows: $\mathrm{G} 1=\mathrm{Ca}(\mathrm{OH})_{2}$ p.a. (Probem, Laboratório de Produtos Farmacêuticos e Odontológicos Ltda, Catanduva, SP, Brazil) with distilled water; $\mathrm{G} 2=\mathrm{Ca}(\mathrm{OH})_{2}$ with polyethylene glycol (PG) (Calen ${ }^{\mathrm{TM}}$ - S.S. White Artigos Dentários Ltda, Rio de Janeiro, RJ, Brazil); $\mathrm{G} 3=\mathrm{Ca}(\mathrm{OH})_{2}$ with $\mathrm{PG}$ and camphorated paramonochlorophenol (CMCP) (Calen PMCCTM- S.S. White Artigos Dentários Ltda); G4= $\mathrm{Ca}(\mathrm{OH})_{2}$ p.a. (Probem) with glycerin. Calen ${ }^{\mathrm{TM}}$ has the following composition: $\mathrm{Ca}(\mathrm{OH})_{2}(49.77 \mathrm{~g} \%)$, zinc oxide, hydrogenised colophony and PG 400, and Calen PMCC TM has the addition of paramonochlorophenol (0.72 $\mathrm{g} \%)$ and camphor $(2.16 \mathrm{~g} \%)$.

In $\mathrm{G} 1$ and $\mathrm{G} 4$, the intracanal dressings were placed with a size 35 Lentullo spiral (Dentsply/Maillefer) while in $\mathrm{G} 2$ and $\mathrm{G} 3$ the intracanal dressings were placed with an endodontic syringe (S.S. White Artigos Dentários Ltda) as recommended by the manufacturer. A small cotton pellet was placed at the canal orifices (6). During all procedures throughout the experiment, the teeth were kept moist and no coronal temporary seal was used.

Five teeth with intact crowns served as negative controls and 5 teeth (from the initial 45 specimens) with instrumented canals with no temporary dressing and opened access cavities served as positive controls.

\section{Polymicrobial Leakage}

The leakage test was conducted based on a twochamber model described by Siqueira et al. (8). Briefly, $10 \mathrm{~mL}$ glass assay tubes (BD Vacutainer ${ }^{\mathrm{TM}}$, Juiz de Fora, MG, Brazil) with fitted rubber stoppers were used in this experiment. A hole was made through the center of each rubber stopper with a heated instrument and insulin syringes (BD Plastipak ${ }^{\circledR}$; Becton Dickinson Ind. Cirúr. Ltda, Curitiba, PR, Brazil) were inserted in these orifices. The tooth crown was inserted under pressure within a rubber hose, which was fixed to the cementoenamel junction. The other side of the rubber hose was adapted to the insulin syringes orifices serving as the upper chamber, being the saliva reservoir. The rubber stopper was then placed in position with the tooth inside the glass tube, containing sterile Brain Heart Infusion broth (BHI, Oxoid LTD., Wade Road, Basingstoke, Hanks, UK) (Fig. 1). 
Two coats of nail varnish were applied on the external surface of all teeth, except $2 \mathrm{~mm}$ around the apical foramen, in order to prevent bacterial leakage through lateral canals or other discontinuities in the cementum. The intersection between syringe/rubber stop, syringe/rubber hose and root/rubber hose were sealed with cyanoacrylate adhesive (Loctite 496, Henkel Ltda, São Paulo, SP, Brazil). The external limit of the apparatus was sealed with cyanoacrylate adhesive and Parafilm M (Laboratory Film, American National Can, Chicago Illinois, USA) (Fig. 1). The testing apparatus was sterilized overnight using ethylene oxide gas (BIOXXI Sterilization Services Ltd., Rio de Janeiro, RJ, Brazil) and the set up was made in a laminar airflow hood (Bioprotector Plus 09, Veco, Campinas, SP, Brazil).

The whole apparatus was incubated at $37^{\circ} \mathrm{C}$ for 4 days to ensure sterilization. Afterwards, the upper chambers were filled with human saliva mixed in BHI broth in a 1:1 (v/v) ratio and replenished every 3 days. The saliva was collected from only one volunteer, who did not brush the teeth for at least $12 \mathrm{~h}$ before collection. Chewing a 1-g piece of Parafilm (American National

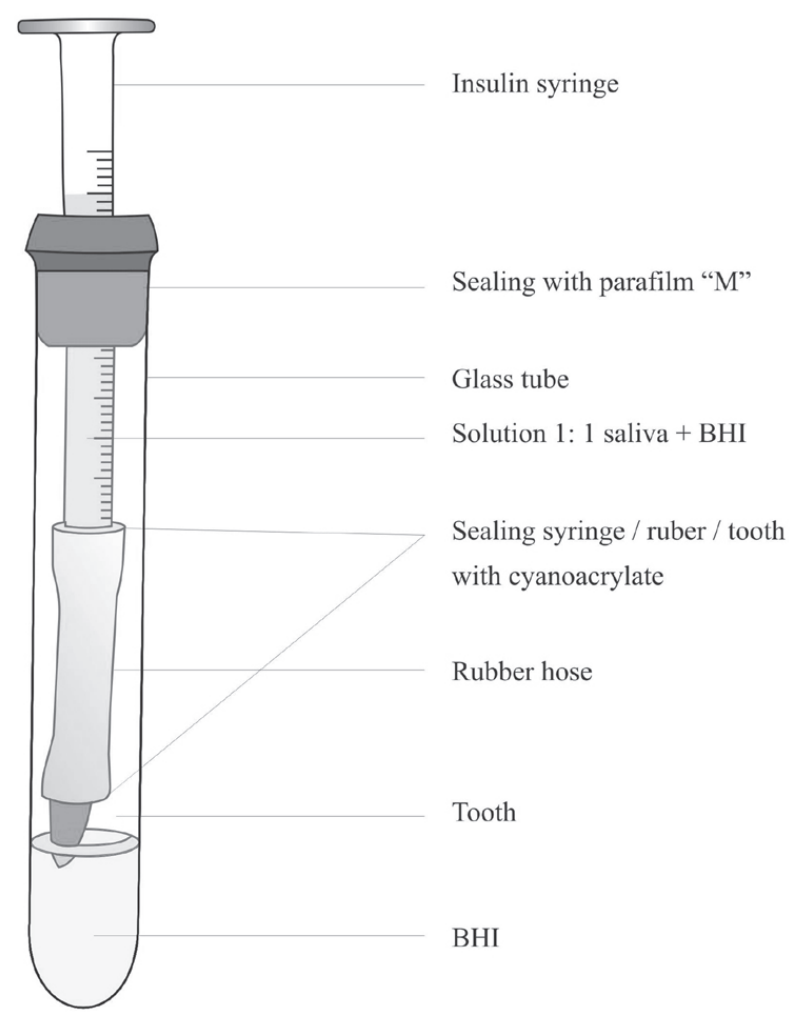

Figure 1. The dual-chamber leakage model design used in this study.
Can, Menasha, WI, USA) was used to stimulate salivary flow (9). The system was incubated at $37^{\circ} \mathrm{C}$ and checked daily for the appearance of turbidity in the BHI broth during the following 9 weeks. Data obtained were statistically analyzed for number of infiltrated samples through time of exposure to the bacterial source.

\section{Statistical Analysis}

Kaplan-Meier method was used to estimate survival curves for each experimental group. The "death" of a specimen was noted at the time in which bacterial leakage first became evident. The long-rank test was used to compare survival curves of the 4 groups. The Friedman's and Wilcoxon tests were used to compare the presence/absence of turbidity among all groups and of each pair of groups. Significance level was set at $5 \%$.

\section{RESULTS}

No growth was observed when checking the sterilization of the whole apparatus. All specimens of the positive control group showed broth turbidity within 3 days of incubation. No leakage was observed in the negative controls during the 9-week experiment. Leakage in experimental samples was first observed at the third day and displayed leakage within a range of 3 to 39 days. After the 39th day of experiment, no specimen presented leakage until the end of the experiment at 63rd day (9 weeks). The number of leaking specimens per group and the leakage range can be seen in Table 1 and Figure 2.

No significant difference was observed when all

Table 1. Pattern of bacterial leakage per group after 63 days of evaluation.

\begin{tabular}{lcccc}
\hline Groups & $\begin{array}{c}\text { Samples } \\
(\mathrm{n})\end{array}$ & $\begin{array}{c}\text { Leakage } \\
\text { Leakage }\end{array}$ & $\begin{array}{c}\text { Range } \\
\text { (days) }\end{array}$ \\
\hline $\mathrm{Ca}(\mathrm{OH})_{2}+\mathrm{DW}(\mathrm{G} 1)$ & 10 & 5 & 5 & $3-33$ \\
$\mathrm{Ca}(\mathrm{OH})_{2}+\mathrm{PG}(\mathrm{G} 2)$ & 10 & 5 & 5 & $3-18$ \\
$\mathrm{Ca}(\mathrm{OH})_{2}+\mathrm{PG}+\mathrm{CMCP}(\mathrm{G} 3)$ & 10 & 1 & 9 & 6 \\
$\mathrm{Ca}(\mathrm{OH})_{2}+$ glycerin $(\mathrm{G} 4)$ & 10 & 8 & 2 & $3-39$ \\
Positive control & 5 & 5 & 0 & 3 \\
Negative control & 5 & 0 & 5 & 0 \\
\hline
\end{tabular}

$\mathrm{DW}=$ distilled water $\mathrm{PG}=$ polyethylene glycol; $\mathrm{CMCP}=$ camphorated paramonochlorophenol. 
groups were compared $(\mathrm{p}=0.08)$. However, the Friedman's test showed significant differences with paired comparisons among the groups when the absence/ presence of turbidity was compared $(\mathrm{p}=0.017)$ and the Wilcoxon test indicated difference between G3 and G4, with $\mathrm{G} 3$ achieving better seal against bacterial leakage than G4 (Fig. 3).

\section{DISCUSSION}

Intracanal medication may be used during endodontic treatment to support chemo-mechanical debride- ment for several reasons (10). In cases of apexification, persistent exudate, or even in cases where there is a lack of time to conclude the endodontic treatment, an intracanal dressing may prevent the penetration of bacteria from saliva in the root canal. These medications can either act as a chemical barrier by killing microorganisms that remain in the root canal, thus preventing their ingress to the root canal or as a physical barrier against bacteria penetration $(4,10)$.

The present study was designed to compare the ability of intracanal medications in prevent bacterial leakage. The present results demonstrate that at the end of 9 weeks, $\mathrm{G} 3\left(\mathrm{Ca}(\mathrm{OH})_{2} / \mathrm{CMCP}\right.$; Calen PMCCTM $)$ had the smallest leakage, however it was only statiscally different from $\mathrm{G} 4$, in which $\mathrm{Ca}(\mathrm{OH})_{2}$ was mixed with glycerin. Siqueira et al. (11) have reported that the chemomechanical preparation with $2.5 \% \mathrm{NaOCl}$ and further 7 day interappointment dressing with a $\mathrm{Ca}(\mathrm{OH})_{2} / \mathrm{CPMC}$ paste significantly increased the number of culture-negative cases.

The superior in vitro antimicrobial activity of the combination of $\mathrm{Ca}(\mathrm{OH})_{2}$ with CMCP has long been recognized. Roach et al. (4) reported that $\mathrm{Ca}(\mathrm{OH})_{2}$ and $\mathrm{Ca}(\mathrm{OH})_{2}$ associated with CMCP inhibited Enterococcus faecalis longer than the $\mathrm{Ca}(\mathrm{OH})_{2}$ points and chlorhexidine. Gomes et al. (5) reported that $\mathrm{Ca}(\mathrm{OH})_{2}$ with CMCP had the strongest antimicrobial activity whereas $\mathrm{Ca}(\mathrm{OH})_{2}$ associated with both sterile water and PG had the weakest. Sukawat and Srisuwan (12) demonstrated that $\mathrm{Ca}(\mathrm{OH})_{2}$ mixed with CMCP was the most effective intracanal medication against E. faecalis (12). However, Siqueira et al. (13), using a polymicrobial leakage model, demonstrated that

Figure 3. Pattern of leakage in the experimental groups. 
$\mathrm{Ca}(\mathrm{OH})_{2}$ in association with saline solution had equal ability to prevent the recontamination of the system when compared to $\mathrm{Ca}(\mathrm{OH})_{2} / \mathrm{CMCP}$. The authors reported that this probably occurred because saliva can dilute and neutralize the antibacterial effects of CMCP released from the calcium hydroxide paste, what does not corroborated with the present study results.

The use of CMCP is based on the antiseptical properties of phenol and chloride ion. In spite of its great antibacterial activity, many authors have suggested that CMCP should have its clinical use limited due to its toxic effects on periapical tissues (14). However, it has been found that periapical tissues had good response to calcium hydroxide paste mixed with CMCP (15). The combination of CMCP with other substances has been proposed to increase its antimicrobial activity and reduce its toxicity. The calcium hydroxide paste mixed with CMCP associated with PG has larger calcium ion liberation and higher $\mathrm{pH}$ means when compared to detergent, saline solution, PG associated with furacyn paramonochlorophenol according to Camargo et al. (16). Zehnder et al. (17) also demonstrated the high capacity of calcium hydroxide to prevent microbial leakage when compared to bioactive glass S53P4.

In disagreement with the present results, Sevimay et al. (18) reported that the application of $\mathrm{Ca}(\mathrm{OH})_{2}$ as a temporary dressing material had no effect on coronal leakage. These results might be attributed to methodological differences. The authors evaluated the leakage by observing linear dye penetration of 61 teeth previously immersed in India Ink for 7 days. Despite its popularity, ease of use and large number of reports, dye leakage has several negative aspects that allow a high variety of results from similar experiments (19). The penetration of the dye can be stopped by entrapped air or the dye can loose its color when it is in contact with some filling materials or strong acidic solutions used to decalcify the tooth and it gives no information of the volume of fluid leaking along the root fillings (19). Also, dyes can give a false positive result due to the molecular size of dye particles which are less than that of bacteria, and can penetrate where bacteria cannot (8). According to Siqueira et al. (20), the dye leakage experimental model is subjective, less comparative and with a low reproducibility. Also, a previous study (10) found no correlation between bacterial and dye leakage.

Bacterial leakage studies allow the evaluation of the samples at specific periods of time and preserve the sample. Nevertheless, it is a static model that does not simulates perfectly the clinical conditions and needs long time of observation $(13,20)$. Many leakage studies using bacterial cultures or human saliva have been widely used to test the sealing ability of endodontic filling materials because it might be more meaningful and provide more precise and reproducible data (19). This method is advantageous because it closely approximates to the real clinical situation simulating the relation between the tooth and the oral flora. However, it is not possible to directly correlate the amount of leakage to the clinical outcomes of endodontic treatments.

Within these limitations of the present study, it may be concluded that the group in which $\mathrm{Ca}(\mathrm{OH})_{2}$ was mixed with $\mathrm{PG}$ and $\mathrm{CMCP}$ achieved a better seal against bacterial leakage than the group in which $\mathrm{Ca}(\mathrm{OH})_{2}$ was mixed with gycerin. Although G3 presented fewer specimens with leakage, this difference was not statistically different from G1 and G2.

\section{RESUMO}

Este estudo in vitro avaliou, por um modelo de infiltração bacteriano, se a medicação intracanal com hidróxido de cálcio associado a diferentes veículos, tem efeito inibitório na penetração coronária de bactéria. Quarenta caninos humanos instrumentados foram medicados com $\mathrm{Ca}(\mathrm{OH})_{2}$ p.a. associados à $\mathrm{G} 1=$ água destilada; $\mathrm{G} 2=$ polietilenoglicol $(\mathrm{PG}) ; \mathrm{G} 3=$ polietilenoglicol e paramonoclorofenol canforado (PMCP); e G4= glicerina. Cinco dentes hígidos foram utilizados como grupo controle negativo e cinco dentes instrumentados sem medicação intracanal serviram como grupo controle positivo. Todos os dentes foram montados em um aparato de duas câmaras e expostos a saliva humana por 63 dias. A infiltração foi verificada através da observação do turvamento do meio de cultura na câmara inferior. Cinqüenta por cento das amostras do G1 e G2, $10 \%$ do G3 e $80 \%$ do G4 foram totalmente contaminadas após 9 semanas. Diferenças estatisticamente significantes foram observadas quando foram realizadas comparações pareadas entre G3 e G4 ( $p=0,0069)$, com G3 alcançando um melhor selamento contra infiltração bacteriana do que G4.

\section{REFERENCES}

1. Siqueira Jr JF, Rôças IN, Santos SRLD, Lima KC, Magalhães FAC, Uzeda M. Efficacy of instrumentation techniques and irrigation regimens in reducing the bacterial population within root canals. J Endod 2002;28:181-184.

2. Chu FCS, Leung WK, Tsang PCS, Chow TW, Samaranayake LP. Identification of cultivable microorganisms from root canals with apical periodontitis following two-visit endodontic treatment with antibiotics/steroid or calcium hydroxide dressings. J Endod 2006;32:17-23.

3. Margura ME, Kafrawy AH, Brown CE, Newton CW. Human 
saliva coronal microleakage in obturated root canals: An in vitro study. J Endod 1991;17:324-331.

4. Roach RP, Hatton JF, Gillespie MJ. Prevention of the ingress of a known virulent bacterium into the root canal system by intracanal medications. J Endod 2001;27:657-660.

5. Gomes BPFA, Ferraz CCR, Garrido FD, Rosalen PL, Zaia AA, Teixeira FB et al.. Microbial susceptibility to calcium hydroxide pastes and their vehicles. J Endod 2002;28:758-761.

6. Pacios MG, La Casa ML, Bulacio MLA, López ME. Calcium hydroxide's association with different vehicles: In vitro action on some dentinal components. Oral Surg Oral Med Oral Pathol Oral Radiol Endod 2003;96:96-101.

7. Sigurdsson A, Stancill R, Madison S. Intracanal placement of $\mathrm{Ca}(\mathrm{OH})_{2}$ : A comparison of techniques. J Endod 1992;18:367369.

8. Siqueira JR JF, Rôças IN, Abad EC, Castro AJR, Gahyva SM, Favieri A. Ability of three root-end filling materials to prevent bacterial leakage. J Endod 2001;27:673-675.

9. Gomes BPFA, Sato E, Ferraz CCR, Teixeira FB, Zaia AA, Souza-Filho FJ. Evaluation of time required for recontamination of coronally sealed canals medicated with calcium hydroxide and chlorhexidine. Int Endod J 2003;36:604-609.

10. Barthel CR, Zaritzki FF, Raab WH-M, Zimmer S. Bacterial leakage in roots filled with different medicaments and sealed with cavit. J Endod 2006;32:127-129.

11. Siqueira JF Jr, Magalhães KM, Rôças IN. Bacterial reduction in infected root canals treated with $2.5 \% \mathrm{NaOCl}$ as an irrigant and calcium hydroxide/camphorated paramonochlorophenol paste as an intracanal dressing. J Endod 2007;33:667-672

12. Sukawat C, Srisuwan T. A comparison of the antimicrobial efficacy of three calcium hydroxide formulations on human dentin infected with Enterococcus faecalis. J Endod 2002;28:102-104.
13. Siqueira Jr JF, Lopes HP, Uzeda M. Recontamination of coronally unsealed root canals medicated with camphorated paramonochlorophenol or calcium hydroxide pastes after saliva challenge. J Endod 1998;24:11-14.

14. Spanberg LSW. Intracanal medication. In: Ingle JI, Barkland LK (Editors). Endodontics. 4th ed. Baltimore: Williams \& Wilkins; 1994. p 627-640.

15. Leonardo MR, Bezerra da Silva LA, Utrilla LS, Leonardo RT, Consolaro A. Effect of intracanal dressing on repair and apical bridging of teeth with incomplete root formation. Endod Dent Traumatol 1993;9:25-30.

16. Camargo CHR, Bernardineli N, Valera MC, de Carvalho CAT, de Oliveira LD, Menezes MM et al.. Vehicle influence on calcium hydroxide pastes diffusion in human and bovine teeth. Dent Traumatol 2006;22:302-306.

17. Zehnder M, Baumgartner G, Marquardt K, Paqué F. Prevention of bacterial leakage through instrumented root canals by bioactive glass S53P4 and calcium hydroxide suspensions in vitro. Oral Surg Oral Med Oral Pathol Oral Radiol Endod 2007; 103:423-428

18. Sevimay S, Öztan MD, Dalat D. Effects of calcium hydroxide paste medication on coronal leakage. J Oral Rehab 2004;31:240-244.

19. Wu MK, Wesselink PR. Endodontic leakage studies reconsidered. Part I. Methodology, application and relevance. Int Endod J 1993;26:37-43.

20. Siqueira Jr JF, Rôças IN, Lopes HP, De Uzeda M. Coronal leakage of two root canal sealers containing calcium hydroxide after exposure to human saliva. J Endod 1999;25:14-16.

Accepted April 17, 2008 